\title{
Nitrogen Release Patterns of a Mixed Controlled-release Fertilizer and Its Components
}

\author{
L. Carolina Medina ${ }^{1}$, Thomas A. Obreza ${ }^{1,3}$, Jerry B. Sartain ${ }^{1}$, \\ and Robert E. Rouse ${ }^{2}$
}

AdDITIONAL INDEX WORDs. nitrogen, coated fertilizer, slow-release fertilizer

Summary. Applying water-soluble nitrogen (N) fertilizer to Florida citrus (Citrus spp.) trees on deep sandy soils may lead to poor nutrient use efficiency and possible nitrate contamination of groundwater if rainfall or irrigation is excessive. Controlled-release fertilizer (CRF) is a possible alternative to increase $\mathbf{N}$ uptake efficiency and minimize losses to the environment, but current grower acceptance is limited as a result of lack of experience with CRF performance and its high relative cost. The objective of this study was to measure the $\mathrm{N}$ release characteristics of a CRF blend (CitriBlen ${ }^{\circledR}$ ) designed for mature Florida citrus trees and its three CRF components [Agrocote ${ }^{\circledR}$ Type A, Agrocote ${ }^{\circledR}$ Type C(D), and Agrocote ${ }^{\circledR}$ Poly-S $^{\circledR}$ ] under laboratory and field conditions. We first characterized $\mathrm{N}$ release from these CRF materials using a 270-day laboratory soil incubation. The quantity of $\mathrm{N}$ released was influenced by CRF material used; after 270 days, cumulative leached $\mathrm{N}$ recoveries were $90 \%, 82 \%, 85 \%$, and $69 \%$ of the total $\mathrm{N}$ applied as CitriBlen ${ }^{\circledR}$, Agrocote $^{\circledR}$ Type A, Agrocote ${ }^{\circledR}$ Type C(D), and Agrocote ${ }^{\circledR}$ Poly-S ${ }^{\circledR}$, respectively. We then measured the $\mathrm{N}$ release patterns of the fertilizers in a 1 -year field evaluation and developed their $\mathbf{N}$ release curves. Studies were simultaneously conducted in central and southwestern Florida. Mesh bags containing $3.5 \mathrm{~g}$ of elemental $\mathrm{N}$ from each source were placed on the soil surface within the irrigated zone under a citrus tree canopy to estimate $\mathbf{N}$ release rates from the fertilizers. Despite differential $\mathbf{N}$ release rates between locations, at 1 year, the rank of $\mathrm{N}$ release was Type $\mathrm{A}>\mathrm{CitriBlen}^{\circledR}>$ Poly-S ${ }^{\circledR}>$ Type $C(D)$. CitriBlen ${ }^{\circledR} \mathrm{N}$ release patterns matched well with the current University of Florida, Institute of Food and Agricultural Sciences citrus fertilization strategy recommended as a best management practice.

$\mathrm{M}$ ost Florida citrus is grown on extremely sandy soils inherently low in fertility, cation exchange capacity, and ability to retain applied plant nutrients. Traditionally, the main way of providing nitrogen $(\mathrm{N})$ to Florida citrus trees has been broadcast applications of ammonium nitrate fertilizer. However, the high water-solubility of this material in combination with Florida's sandy soils and humid conditions can cause poor nutrient use efficiency and leaching of nitrate $\mathrm{N}\left(\mathrm{NO}_{3}-\mathrm{N}\right)$ below the root zone. A circa 1990 Florida groundwater quality study revealed nitrate pollution of some central Florida drinking water wells located close to mature commercial citrus orchards (Lamb et al., 1999).

${ }^{1}$ Soil and Water Science Department, University of Florida, 2169 McCarty Hall, P.O. Box 110290 , Gainesville, FL 32611

${ }^{2}$ Horticultural Sciences Department, University of Florida, Southwest Florida Research and Education Center, 2686 State Road 29 North, Immokalee, FL 34142

${ }^{3}$ Corresponding author. E-mail: obreza@ufl.edu.
Efficient nutrient management practices, including the use of controlledrelease fertilizer technology, may improve $\mathrm{N}$ use efficiency and decrease the potential for $\mathrm{N}$ loss to the environment.

Controlled-release fertilizer is formulated to gradually deliver nutrients to plants at a rate that matches the physiological requirement (Oertli, 1980). Recent studies have shown that controlled-release fertilizer (CRF) applied as part of a citrus fertilization program could reduce $\mathrm{N}$ leaching on Florida sandy soils (Alva and Tucker, 1993; Dou and Alva, 1998; Wang and Alva, 1996). Reports have also indicated that comparable or improved citrus yield and quality was obtained from trees fertilized with CRF compared with water-soluble forms (Alva and Paramasivam, 1998; Koo, 1986; Obreza et al., 1999; Zekri and Koo, 1992). Obreza et al. (2006) found that fruit yield of mature 'Hamlin' orange (Citrus sinensis) trees was greater with a resin/Poly- $S^{\circledR}$ (Scotts Co., Marysville, $\mathrm{OH}$ ) mixture applied once annually at $90 \mathrm{lb} /$ acre $\mathrm{N}$ when compared with water-soluble fertilizer applied at $180 \mathrm{lb} /$ acre $\mathrm{N}$ per year in three equal doses. The use of CRF in the Florida citrus industry has been limited because of higher cost compared with water-soluble fertilizer and the lack of familiarity about its field performance. However, government regulatory agencies are now investigating if using CRF to fertilize citrus could be considered a best management practice (BMP), mainly in the central Florida ridge area where groundwater pollution is a concern.

Even if CRF use becomes economical, widespread acceptance by citrus growers will likely be limited as a result of grower concern about field performance. For example, nutrient release patterns determined by the manufacturer in the laboratory or greenhouse sometimes have not correlated well with release in the field. A study by Meadows and Fuller (1983) revealed that nutrient release periods of several polymer-coated fertilizers were shorter than those claimed by the manufacturers. Efforts have been made during the last decade to develop models describing nutrient release from coated fertilizers. Most of these models assumed that nutrient release from coated fertilizers is controlled either by the rate of solute diffusion from the fertilizer or by the rate of water vapor penetration into the granule through the

\begin{tabular}{llll}
\hline $\begin{array}{l}\text { Units } \\
\text { To convert U.S. to SI, } \\
\text { multiply by }\end{array}$ & U.S unit & SI unit & $\begin{array}{l}\text { To convert SI to U.S., } \\
\text { multiply by }\end{array}$ \\
\hline 29.5735 & $\mathrm{fl} \mathrm{oz}$ & $\mathrm{mL}$ & 0.0338 \\
0.3048 & $\mathrm{ft}$ & $\mathrm{m}$ & 3.2808 \\
3.7854 & gal & $\mathrm{L}$ & 0.2642 \\
2.54 & inch(es) & $\mathrm{cm}$ & 0.3937 \\
25.4 & inch(es) & $\mathrm{mm}$ & 0.0394 \\
1.1209 & $\mathrm{lb} / \mathrm{acre}$ & $\mathrm{kg} \cdot \mathrm{ha}^{-1}$ & 0.8922 \\
28.3495 & $\mathrm{oz}$ & $\mathrm{g}$ & 0.0353 \\
28,350 & $\mathrm{oz}$ & $\mathrm{mg}$ & $3.5274 \times 10^{-5}$ \\
$\left({ }^{\circ} \mathrm{F}-32\right) \div 1.8$ & ${ }^{\circ} \mathrm{F}$ & ${ }^{\circ} \mathrm{C}$ & $\left(1.8 \times{ }^{\circ} \mathrm{C}\right)+32$
\end{tabular}

Hartecthology · July-September 2008 18(3) 
coating (Shaviv, 2001). According to Sharma (1979), the most direct and widely used technique to evaluate $\mathrm{N}$ release characteristics is CRF incubation in soil where some or all of the mineral $\mathrm{N}$ released with time is determined. Information regarding the release periods and characteristics of individual CRFs is needed to expand commercial use of CRF for citrus production.

The objectives of this study were: 1) to characterize the nature of $\mathrm{N}$ release from a CRF blend designed for mature Florida citrus trees and its individual CRF components using a standard laboratory lysimeter incubation; 2) to measure the $\mathrm{N}$ release characteristics of the fertilizers in a 1-year field evaluation; and 3 ) to develop $\mathrm{N}$ release curves for the selected CRF. The results will help determine the efficacy of the evaluated CRF materials to provide $\mathrm{N}$ in a citrus nutrient BMP program.

\section{Materials and methods}

Nitrogen release rates of CitriBlen $^{\circledR}$ (Scotts Co.), a mixture of coated and noncoated water-soluble nutrients produced to fertilize mature Florida citrus trees (Table 1), and its three coated components [Agrocote ${ }^{\circledR}$ Type A, Agrocote ${ }^{\circledR}$ Type C(D), and Agrocote $^{\circledR}$ Poly- $S^{\circledR}$; Scotts Co.] were evaluated under greenhouse and field conditions. In addition to the three Agrocote $^{\circledR}$ materials, CitriBlen ${ }^{\circledR}$ also contained a water-soluble $21 \mathrm{~N}-$ 3.1P-11.6K material (Hydro ${ }^{\circledR}$; Yara North America, Tampa, FL), potassium-magnesium sulfate, and potassium chloride.

LABORATORY CHARACTERIZATION UNDER STANDARD CONDITIONS. Sartain et al. (2004) developed a lysimeter leaching technique to characterize nutrient release from fertilizers under standard soil, temperature, and moisture conditions. This method was used to gain an initial understanding of how $\mathrm{N}$ is temporally released from CitriBlen ${ }^{\circledR}$ and from the CRF components that compose it. The steps in this technique were as follows: $90 \mathrm{~g}$ of Arredondo fine sand (Loamy siliceous, hyperthermic, Grossarenic Paleudult) surface soil $(0$ to $5 \mathrm{~cm})$ from the field was mixed with $1710 \mathrm{~g}$ of noncoated quartz sand. The purpose of adding the field soil was to introduce the biotic component of a natural system. The next step was to incorporate the amount of the fertilizer under evaluation required to supply $450 \mathrm{mg} \mathrm{N}$ to the system. The soil-fertilizer mixture was placed in a 12 -inch-long, 3 -inchdiameter polyvinyl chloride (PVC) lysimeter and was then brought to $10 \%$ soil moisture by adding $180 \mathrm{~mL}$ of $0.01 \%$ citric acid solution (used to provide a readily degradable carbon source for microbes). Before covering with a PVC cap, a $50-\mathrm{mL}$ beaker containing $20 \mathrm{~mL}$ of $0.2 \mathrm{M}$ sulfuric acid was placed in the head space of the lysimeter as an ammonia trap. The unit was incubated at $\approx 75^{\circ} \mathrm{F}$ in a greenhouse. The solution in the ammonia trap was replaced and analyzed for ammonium $\mathrm{N}\left(\mathrm{NH}_{4}-\mathrm{N}\right)$ by titration every $7 \mathrm{~d}$ to determine volatilized $\mathrm{N}$ during the incubation period.

The incubation experiment used 24 lysimeters in a randomized complete block design with six treatments $\left(\right.$ CitriBlen ${ }^{\circledR}$, its three CRF components, Hydro ${ }^{\circledR}$ fertilizer, and a nofertilizer control) and four replications. Each lysimeter was leached 12 times
$(7,14,28,42,56,84,112,140,180$, 210,240 , and $270 \mathrm{~d}$ after starting the incubation) with one pore volume $(500 \mathrm{~mL})$ of $0.01 \%$ citric acid. The leaching solution was evacuated by placing each lysimeter under vacuum for 2 min. Leachate volume was recorded and an aliquot was frozen for subsequent $\mathrm{N}$ analysis. Leachates were analyzed for $\mathrm{NO}_{3}-\mathrm{N}$ and $\mathrm{NH}_{4}-$ $\mathrm{N}$ concentration using an Alpkem 300 rapid-flow analyzer (O I Analytical Corp., College Station, TX). The concentration of urea- $\mathrm{N}$ was measured using a colorimetric method (Bremner, 1982). The weight of each form of $\mathrm{N}$ leached was determined by multiplying $\mathrm{N}$ concentration by leachate volume. Total weight of $\mathrm{N}$ released with time was estimated by adding the three forms of $\mathrm{N}$ present in the leachate and the volatilized N.

Evaluation of Nitrogen RELEASE IN THE FIELD. A l-year experiment was carried out in two mature citrus tree orchards to measure $\mathrm{N}$ release patterns of CitriBlen ${ }^{\circledR}$ and its components under natural temperature and moisture conditions. Studies were initiated in Feb. 2004 in two of Florida's major citrusgrowing regions, Lake Alfred in central Florida and Immokalee in southwestern Florida. Flat bags $(5 \times 5$ inches) were constructed from two pieces of $18 \times 16$-mesh fiberglass window screen using heat to seal the edges. The study used 330 mesh bags at each location in a randomized complete block design (five fertilizer treatments $\times 11$ retrieval dates $\times$ six replications). Bags were filled with CitriBlen ${ }^{\circledR}$, one of the three Agrocote ${ }^{\circledR}$ materials, or water-soluble $\mathrm{N}-\mathrm{P}-\mathrm{K}$ (ammonium nitrate, concentrated superphosphate, and potassium

Table 1. Controlled-release fertilizer (CRF) specified duration, macronutrient analysis, distribution of nitrogen (N) forms, and nutrient sources inside the coating of each material.

\begin{tabular}{|c|c|c|c|c|c|c|c|c|}
\hline \multirow[b]{2}{*}{ Fertilizer } & \multirow{2}{*}{$\begin{array}{c}\text { Release } \\
\text { duration }(\mathrm{mo})^{\mathrm{z}}\end{array}$} & \multirow[b]{2}{*}{ Analysis (\%) } & \multicolumn{3}{|c|}{$\begin{array}{c}\text { Distribution of } N \\
\text { forms (\% of total } N \text { ) }\end{array}$} & \multicolumn{3}{|c|}{$\begin{array}{l}\text { Fertilizer sources } \\
\text { coated }^{\mathrm{y}}\end{array}$} \\
\hline & & & Ammonium & Nitrate & $\mathrm{WSON}^{\mathrm{x}}$ & $\mathbf{N}$ & $\mathbf{P}$ & $\mathbf{K}$ \\
\hline CitriBlen $^{\circledR \mathrm{w}}$ & 12 & $15 \mathrm{~N}-1.3 \mathrm{P}-15.8 \mathrm{~K}$ & 35 & 30 & 35 & $\mathrm{AN}, \mathrm{AP}, \mathrm{PCSU}$ & $\mathrm{AP}, \mathrm{CP}$ & $\mathrm{K}-\mathrm{MgS}, \mathrm{KS}$ \\
\hline Agrocote $^{\circledR}$ Type A & 3 to 4 & $19 \mathrm{~N}-2.6 \mathrm{P}-10 \mathrm{~K}$ & 53 & 47 & 0 & $\mathrm{AN}, \mathrm{AP}$ & $\mathrm{AP}, \mathrm{CP}$ & KS \\
\hline Agrocote $^{\circledR}$ Type C(D) & 12 to 14 & $18 \mathrm{~N}-3.1 \mathrm{P}-10 \mathrm{~K}$ & 56 & 44 & 0 & $\mathrm{AN}, \mathrm{AP}$ & $\mathrm{AP}, \mathrm{CP}$ & KS \\
\hline Agrocote $^{\circledR}$ Poly-S ${ }^{\circledR}$ & 6 & $37 \mathrm{~N}-0 \mathrm{P}-0 \mathrm{~K}$ & 0 & 0 & 100 & PCSU & - & - \\
\hline
\end{tabular}

${ }^{\mathrm{z}}$ As specified by the manufacturer at $70^{\circ} \mathrm{F}\left(21.1^{\circ} \mathrm{C}\right)$ soil temperature.

${ }^{y} \mathrm{AN}=$ ammonium nitrate; $\mathrm{AP}=$ ammonium phosphate; $\mathrm{PCSU}=$ polymer-coated, sulfur-coated urea; $\mathrm{CP}=$ calcium phosphate; $\mathrm{K}-\mathrm{MgS}=$ potassium-magnesium sulfate; $\mathrm{KS}=$ potassium sulfate.

${ }^{x}$ Water-soluble organic $\mathrm{N}$ (primarily urea).

wAll CRFs are products of Scotts Co., Marysville, OH. CitriBlen ${ }^{\circledR}$ is composed of coated nutrients $\left[\right.$ Agrocote ${ }^{\circledR}$ Type A; Agrocote ${ }^{\circledR}$ Type C $(\mathrm{D})$ and Agrocote ${ }^{\circledR}$ Poly-S ${ }^{\circledR}$ and water-soluble nutrients [Hydro ${ }^{\circledR} 21 \mathrm{~N}-3.1 \mathrm{P}-11.6 \mathrm{~K}$; Yara North America, Tampa, FL, K-MgS, potassium chloride, and iron (EDTA)] 
chloride as a standard fertilizer control). Each bag initially held $3.5 \mathrm{~g}$ of total N. One replication of each fertilizer treatment $\times$ retrieval date combination ( 55 bags) was attached to the ground surface beneath a mature orange tree in a radial "spoke" pattern with respect to the microsprinkler (Fig. 1). The five fertilizer treatments were randomly assigned within each spoke, and subsequently each spoke was randomly assigned a retrieval date. Six adjacent trees were used as replicates. The standard fertilizer treatment was replenished in May and September, mimicking three split applications. There was no replenishment of the CRF treatments after they were initially placed on the soil.

The bags were lightly covered with orchard floor debris (leaves, small twigs, and so on) that had been raked away before setting and securing the bags. Both orchards were under a herbicide program that kept a nearly weed-free soil surface under the tree canopy so plant cover did not interfere with bag placement. The microenvironment in which the fertilizers resided mimicked typical nonincorporated surface fertilizer applications made in commercial Florida citrus operations. Wetting of the fertilizers by rainfall or irrigation was assumed to be uniform within the microsprinkler wetting pattern.

Irrigation scheduling was based on rainfall frequency and season of the year. Most irrigation water was

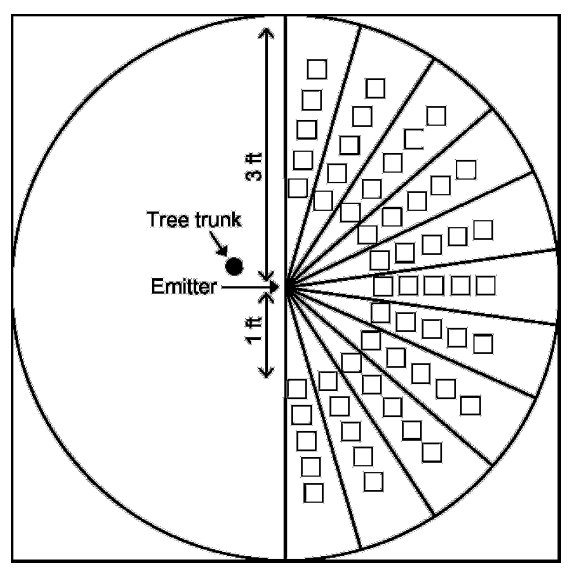

Fig. 1. Placement of mesh bags representing one replication of each fertilizer treatment $\times$ retrieval date combination under the citrus tree canopy. The five fertilizer treatments were randomized within each "spoke" of the pattern, and each spoke represented one retrieval date. applied during the spring and fall dry seasons. In southwestern Florida, microsprinklers with a delivery rate of $16 \mathrm{gal} / \mathrm{h}$ irrigated the trees three times per week at $4 \mathrm{~h}$ per application. In central Florida, microsprinklers delivering $15 \mathrm{gal} / \mathrm{h}$ irrigated twice per week at $4 \mathrm{~h}$ per application. Average daily ambient temperature $2 \mathrm{ft}$ above the ground and daily rainfall volume were collected from Florida Automated Weather Network stations located within 0.3 mile of each site.

One set (six replications $\times$ five fertilizer treatments) of mesh bags were retrieved $14,28,42,60,90$, $120,150,180,240,300$, or $360 \mathrm{~d}$ after they were placed in the field. The bags and residual fertilizer particles within were gently removed from the orchard floor and immediately placed into plastic bags. Mesh bags were subsequently air-dried in a greenhouse and stored at room temperature for later analysis. The particles were homogenized with $150 \mathrm{~mL}$ of deionized water in a blender to destroy remaining coatings and dissolve fertilizer residues. After all particles were emulsified, they were boiled in $25 \mathrm{~mL}$ of concentrated hydrochloric acid on a hot plate for $5 \mathrm{~min}$ followed by analysis of the solution for urea-N, $\mathrm{NO}_{3}-\mathrm{N}$, and $\mathrm{NH}_{4}-\mathrm{N}$ using methods identical to those in the lysimeter study. Total residual $\mathrm{N}$ was calculated by adding the three measured $\mathrm{N}$ forms together. The amount of $\mathrm{N}$ released from each mesh bag was estimated by subtracting the weight of residual $\mathrm{N}$ from the $3.5 \mathrm{~g}$ of $\mathrm{N}$ applied.

Data obtained from both experiments were statistically analyzed using the general linear model procedure of SAS (v9.0; SAS Institute, Cary, NC). Treatment means from the lysimeter experiment were compared with Duncan's multiple range test $(\alpha=0.05)$. Treatment mean separation for the field experiment was accomplished with single df contrasts. Nonlinear regression was used to describe $\mathrm{N}$ release with time separately for each fertilizer at each location to develop $\mathrm{N}$ release curves.

\section{Results and discussion}

LABORATORY CHARACTERIZATION. Volatilization of N was detected during the first $14 \mathrm{~d}$ of incubation only, amounting to less than $1 \%$ of total $\mathrm{N}$

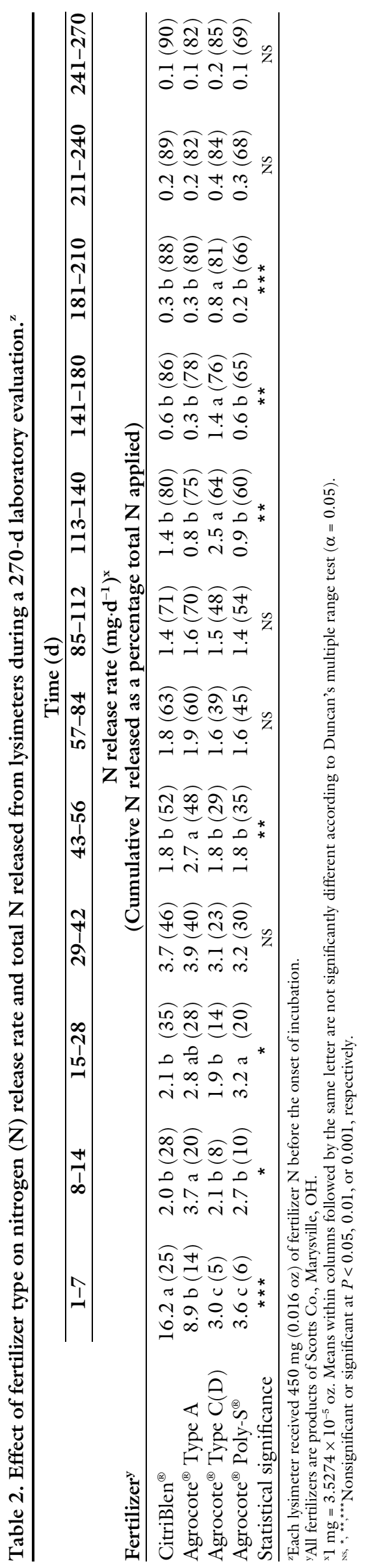


Table 3. Cumulative nitrogen released from mesh bags placed in the field as a percentage of initial weight of nitrogen $(\mathrm{N}){ }^{\mathrm{z}}$

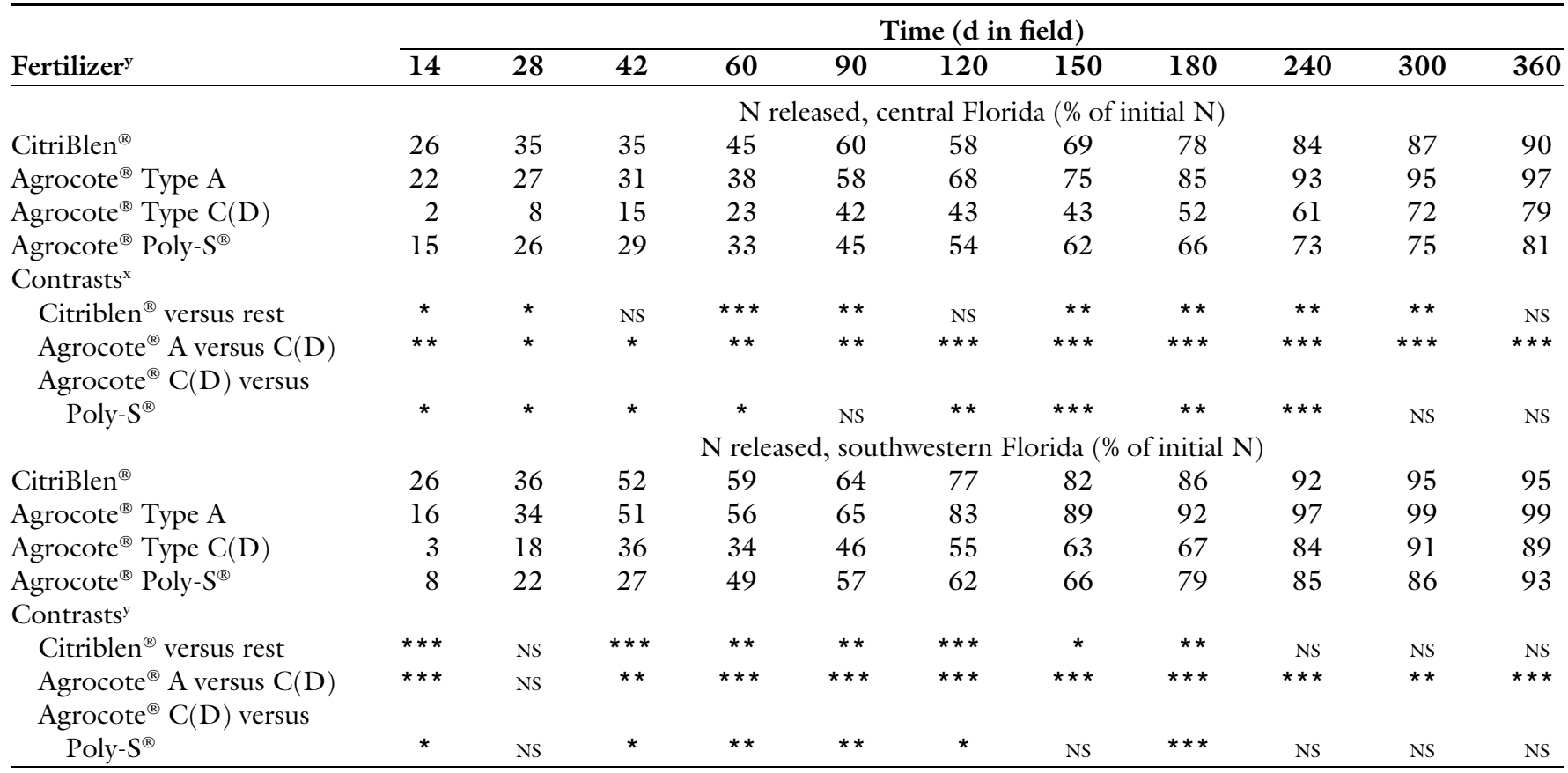

${ }^{z}$ The fertilizer $\times$ location interaction was statistically significant $(P<0.05)$ at $42,150,240,300$, and $360 \mathrm{~d}$.

yAll fertilizers are products of Scotts Co., Marysville, OH.

xSingle df contrasts.

ss, *,**,*** Nonsignificant or significant where $P<0.05,0.01$, and 0.001 , respectively.

applied. Thus, volatilization was considered insignificant as a pathway of $\mathrm{N}$ loss, and the $\mathrm{N}$ forms captured during leaching were assumed to represent $\mathrm{N}$ released from the fertilizers. The proportion of $\mathrm{NO}_{3}-\mathrm{N}$ in 12 leachate fractions was greater than either urea-N or $\mathrm{NH}_{4}-\mathrm{N}$ regardless of fertilizer source. This result showed nitrification was taking place and thus suggested that the system was microbiologically active, mimicking conditions of a natural soil.

During the first $7 \mathrm{~d}$ of incubation, CitriBlen released $\mathrm{N}$ at a significantly greater rate $(25 \%$ of total $\mathrm{N}$ added) compared with the other fertilizers as a result of its watersoluble $\mathrm{N}$ component $\left(\mathrm{Hydro}^{\circledR}\right.$ ) (Table 2). From that point, its CRF components controlled the $\mathrm{N}$ release rate, peaking during the 29 - to $42-\mathrm{d}$ interval. From 43 to $140 \mathrm{~d}$, the release rate was slightly less than half the peak rate and then gradually decreased to near zero by day 270 . Thus, our initial characterization of CitriBlen was: $25 \%$ of total $\mathrm{N}$ released on application, $50 \%$ released in $\approx 2$ months, $75 \%$ released in $\approx 4$ months, and $90 \%$ released in 9 months.

As expected, the three Agrocote $^{\circledR}$ CRF components of CitriBlen ${ }^{\circledR}$ showed different temporal $\mathrm{N}$ release characteristics (Table 2). We observed statistically significant differences in $\mathrm{N}$ release rate for seven of the 12 sampling periods during the incubation. The rank of $\mathrm{N}$ release from fastest to slowest for the first $40 \%$ of the incubation period (112 d) was Type $A>$ Poly-S ${ }^{\circledR}>$ Type C(D), which was the expected ranking based on release periods supplied by the manufacturer (Table 1). However, by day 140, Poly-S ${ }^{\circledR}$ and Type C(D) reversed order because the rate of $\mathrm{N}$ release from Poly- $S^{\circledR}$ slowed considerably after day 112, whereas Type $\mathrm{C}(\mathrm{D})$ continued a relatively rapid release rate through day 180. After

Table 4. Nonlinear regression analysis of estimated 360-d nitrogen $(\mathrm{N})$ release from CitriBlen and its CRF components using exponential rise-to-maximum models.

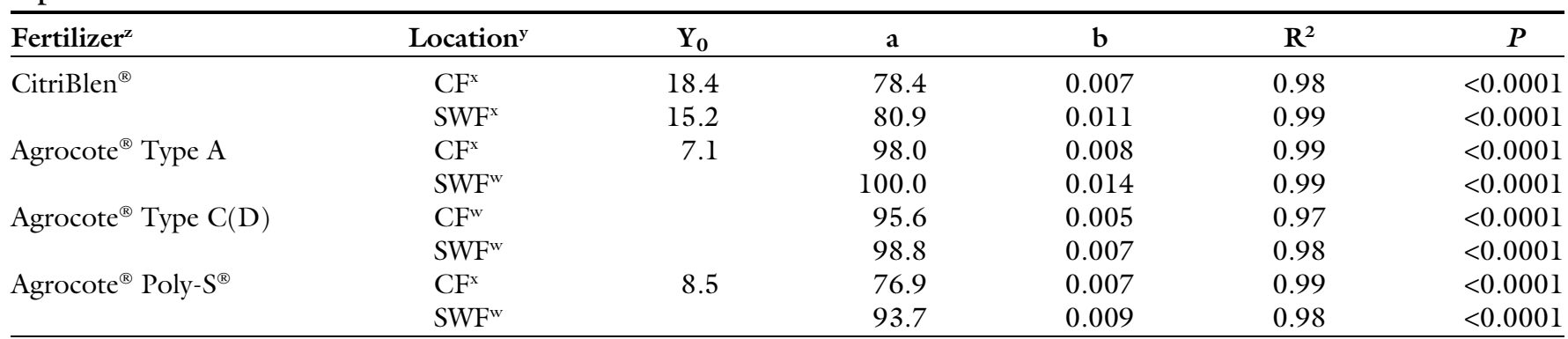

${ }^{\mathrm{z}}$ All fertilizers are products of Scotts Co., Marysville, OH.

${ }^{y} \mathrm{CF}=$ central Florida; SWF $=$ southwestern Florida.

${ }^{x} \mathrm{Y}=\mathrm{Y}_{0}+\mathrm{a}\left(\mathrm{l}-\mathrm{e}^{-\mathrm{bx}}\right)$, where $\mathrm{Y}=\mathrm{N}$ released as a percentage of total $\mathrm{N}$ applied, $\mathrm{X}=$ time $(0$ to $360 \mathrm{~d}$ after application $)$, and $\mathrm{Y}_{0}=\% \mathrm{~N}$ released at time zero; a and $\mathrm{b}$ are regression coefficients.

w $\mathrm{Y}=\mathrm{a}\left(\mathrm{l}-\mathrm{e}^{-\mathrm{bx}}\right)$, where $\mathrm{Y}=\mathrm{N}$ released as a percentage of total $\mathrm{N}$ applied and $\mathrm{X}=$ time $(0$ to $360 \mathrm{~d}$ after application $)$; a and $\mathrm{b}$ are regression coefficients. 
$270 \mathrm{~d}$, cumulative leached $\mathrm{N}$ recoveries were $90 \%, 82 \%, 85 \%$, and $69 \%$ of the total $\mathrm{N}$ applied as CitriBlen ${ }^{\circledR}$, Type A, Type C(D), and Poly-S ${ }^{\circledR}$, respectively. We suspect the lower $\mathrm{N}$ recovery from Poly- $S^{\circledast}$ was the result of $\mathrm{N}$ left inside the fertilizer particles after $270 \mathrm{~d}$ because our previous experience with this material showed a longer release period (Obreza et al., 2006).

Field evaluation. Shortly after placing the mesh bags in the field, it became clear that their physical characteristics and placement would not hinder movement of $\mathrm{N}$ outward to the soil. A 2-inch rainfall that occurred in southwestern Florida during the first week after placement removed all fertilizer from the bags containing the water-soluble $\mathrm{N}-\mathrm{P}-\mathrm{K}$ treatment. The effect of this heavy rainfall on fertilizer $\mathrm{N}$ loss demonstrated the value of fertilizer coatings in preventing rapid $\mathrm{N}$ dissolution and potential leaching. Although 100\% of the ammonium nitrate applied moved out of the bags in the first $14 \mathrm{~d}$ after placement (data not shown), only $3 \%$ to $16 \%$ of total $\mathrm{N}$ in the Agrocote ${ }^{\circledR}$ fertilizer treatments was released (Table 3 ).

Statistical analysis of $\mathrm{N}$ release data revealed a significant fertilizer $\times$ location interaction for five of the 11 mesh bag retrieval times, including the final three retrievals (Table 3 ). By $240 \mathrm{~d}$, cumulative $\mathrm{N}$ release from all coated fertilizer treatments averaged $15 \%$ greater in southwestern Florida than in central Florida (this difference decreased to $8 \%$ by 360 d). We first considered temperature, rainfall, and irrigation as the most likely environmental factors that could have caused differential $\mathrm{N}$ release rates. The mean air temperatures during the study period were nearly identical (72.1 and $71.6{ }^{\circ} \mathrm{F}$ for southwestern and central Florida, respectively), so we concluded that temperature was not a factor. Likewise, rainfall volume was similar between locations $(32.6$ and 33.6 inches for southwestern and central Florida, respectively), but there were $92 \mathrm{~d}$ in which rainfall was recorded in southwestern Florida compared with $77 \mathrm{~d}$ in central Florida. Approximately twice as much irrigation water was applied in southwestern Florida (64.3 inches applied to the wetted zone) compared with central Florida (33 inches). Thus, fertilizer exposure to water in southwestern Florida was greater in both volume and frequency.

We surmised that the slower $\mathrm{N}$ release rates observed in central Florida were the result of more intermittent drying of the fertilizer particles between wetting by irrigation or rainfall. Similar results were found by Kochba et al. (1990). Furthermore, differences in tree row orientation (north-south in southwestern Florida and east-west in central Florida) may have also contributed to this effect. In citrus orchards, more sunlight is intercepted by trees planted in north-south rows compared with east-west rows (Tucker et al., 1992). The amount of direct sunlight striking the fertilizers was greater in central Florida compared with southwestern Florida, which is consistent with the idea of more wetting-drying cycles in central Florida. Nutrient movement through the fertilizer coatings depended on a solute concentration gradient that in turn depends on a consistently moist environment. Interruptions of the gradient resulting from drying likely extended the time required for $\mathrm{N}$ release.

As observed in the laboratory characterization, CitriBlen ${ }^{\circledR}$ released approximately one-fourth of its $\mathrm{N}$ within the first 2 weeks after field application, showed peak $\mathrm{N}$ release from coated components between 1 and 2 months after application, and then gradually continued to release $\mathrm{N}$ at a slower rate through $360 \mathrm{~d}$ (Table 3). At 1 year, CitriBlen ${ }^{\circledR}$ had released $90 \%$ to $95 \%$ of its total $\mathrm{N}$, which was within $10 \%$ or less of design performance.

Similar to the lysimeter incubation, the three Agrocote $^{\circledR}$ fertilizers released $\mathrm{N}$ at different rates in the field when compared with one another (Table 3). The rank of $\mathrm{N}$ release from fastest to slowest for the first 6 months in the field was Type $\mathrm{A}>$ Poly- $\mathrm{S}^{\circledR}>$ Type C(D). After $\approx 8$ months, total $\mathrm{N}$ released by Type $\mathrm{C}(\mathrm{D})$ and Poly-S ${ }^{\circledR}$ was approximately the same. At 1 year, the rank of $\mathrm{N}$ release was Type $\mathrm{A}>$ Poly-S ${ }^{\circledR}=$ Type C(D). Type A was rated as a 3- to 4month $\mathrm{N}$ release material, but after 4 months in our field study, it released $68 \%$ and $83 \%$ of total $\mathrm{N}$ in central and southwestern Florida, respectively. Interestingly, Type A released $75 \%$ of total $\mathrm{N}$ (the mean of the two field values) after $\approx 4$ months in the lysimeters where the material was soilincorporated. It was initially thought that surface-applying the materials would slow their rate of $\mathrm{N}$ release, but this was not the case. Type A and Poly- $S^{\circledR}$ actually released $\mathrm{N}$ faster when surface-applied in the field compared with the lysimeter characterization method, possibly as a result

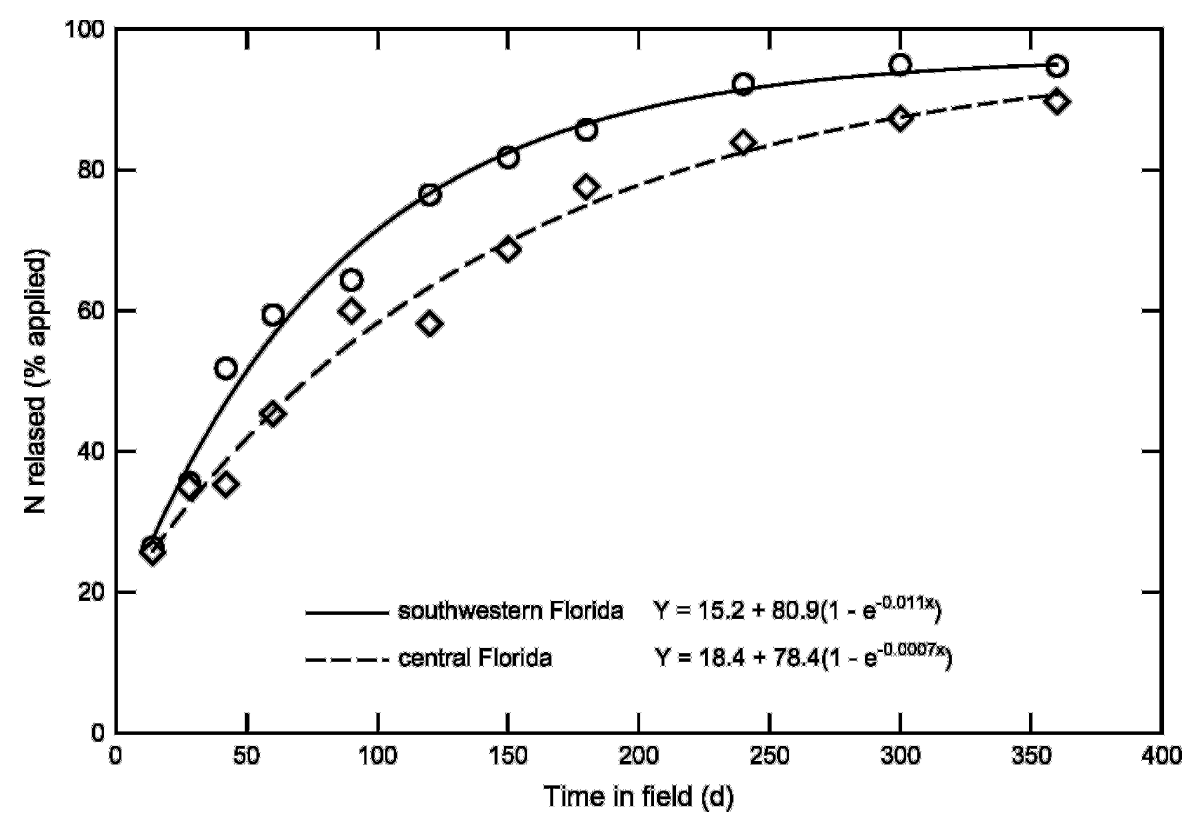

Fig. 2. Nitrogen release curves for CitriBlen ${ }^{\circledR}$ (Scotts Co., Marysville, OH) fertilizer measured in central and southwestern Florida. 
of greater leaching intensity in the field.

Nitrogen release curves for CitriBlen $^{\circledR}$ and the Agrocote ${ }^{\circledR}$ materials fit well to exponential rise-to-maximum models (Table 4). These equations could be used to predict $\mathrm{N}$ release from CitriBlen ${ }^{\circledR}$ throughout the year after its application in a citrus orchard. Current University of Florida-Institute of Food and Agricultural Sciences citrus fertilizer guidelines (Obreza and Morgan, 2007) recommend that two-thirds of the annual orchard $\mathrm{N}$ requirement should be available to the trees between 1 Mar. and 15 June (105 d period) and the remaining one-third should be available throughout the summer and early fall. CitriBlen ${ }^{\circledR} \mathrm{N}$ release curves (Fig. 2) indicate that after $105 \mathrm{~d}$ in the field, $\approx 60 \%$ and $70 \%$ of total $\mathrm{N}$ applied was released in central and southwestern Florida, respectively. The rest of the $\mathrm{N}$ was gradually released until termination of the 1-year field experiment. Thus, the CitriBlen ${ }^{\circledR} \mathrm{N}$ release pattern matched well with the standard recommendation. This information may help increase citrus grower acceptance of CRF for citrus production. We believe CitriBlen ${ }^{\circledR}$ could effectively be used in a citrus fertilization BMP program in Florida.

\section{Literature cited}

Alva, A.K. and S. Paramasivam. 1998. Nitrogen management for high yield and quality of citrus in sandy soils. Soil Sci. Soc. Amer. J. 62:1335-1342.
Alva, A.K. and D.P.H. Tucker. 1993 Evaluation of a resin coated nitrogen fertilizers for young citrus trees on a deep sand. Proc. Florida State Hort. Soc. 106:4-8.

Bremner, J.M. 1982. Nitrogen-urea. p. 699-705. In: Methods of soil analysis, Part 2. Chemical and microbiological properties. Agronomy Monograph no. 9. 2nd ed. ASA-SSSA, Madison, WI.

Dou, H. and A.K. Alva. 1998. Nitrogen uptake and growth of two citrus rootstock seedlings in a sandy soil receiving different controlled-release fertilizer sources. Biol. Fertil. Soils 26:169-172.

Kochba, M., S. Gambash, and Y. Avnimelech. 1990. Studies on slow release fertilizers: 1. Effects of temperature, soil moisture, and water vapor pressure. Soil Sci. 149(6):339-343.

Koo, R.C.J. 1986. Controlled-release sources of nitrogen for bearing citrus. Proc. Florida State Hort. Soc. 99:4648.

Lamb, S.T., W.D. Graham, C.B. Harrison, and A.K. Alva. 1999. Impact of alternative citrus management practices on groundwater nitrate in the Central Florida Ridge: Part 1. Field investigation. Trans. Amer. Soc. Agr. Eng. 42:16531668.

Meadows, W.A. and D.L. Fuller. 1983. Nitrogen and potassium release patterns of five formulations of Osmocote fertilizers and two micronutrient mixes for container-grown woody ornamentals. Proc. Southern Nurserymen's Assn. Res. Conf. 9:28-34.

Obreza, T.A. and K.T. Morgan. 2007. Nutrition of Florida citrus trees. Vol. 2. Univ. of Florida-Institute of Food and
Agricultural Sciences, Soil and Water Science Dept. SL 253.

Obreza, T.A., R.E. Rouse, and E.A. Hanlon. 2006. Advancements with controlled-release fertilizers for Florida citrus production: 1996-2006. Univ. of Florida-Institute of Food and Agricultural Sciences, Soil and Water Science Dept. SL 243.

Obreza, T.A., R.E. Rouse, and J.B. Sherrod. 1999. Economics of controlledrelease fertilizer use on young citrus trees. J. Production Agr. 12:69-73.

Oertli, J.J. 1980. Controlled-release fertilizers. Fert. Res. 1:103-123.

Sartain, J.B., W.L. Hall, R.C. Littell, and E.W. Hopwood. 2004. New tools for the analysis and characterization of slowrelease fertilizers, p. 180-195. In: Environmental impact of fertilizer on soil and water. Amer. Chem. Soc. Symp. Ser. 872. Washington. DC.

Sharma, G.C. 1979. Controlled-release fertilizers and horticultural applications. Scientia Hort. 11:107-129.

Shaviv, A. 2001. Advances in controlledrelease fertilizers. Adv. Agron. 71:1-49.

Tucker, D.P.H., T.A. Wheaton, and R.P. Muraro. 1992. Citrus tree spacing. Univ. of Florida-Institute of Food and Agricultural Science, Horticultural Sciences Dept. HS 143.

Wang, F.L. and A.K. Alva. 1996. Leaching of nitrogen from slow-release urea sources in sandy soils. Soil Sci. Soc. Amer. J. 60:1454-1458.

Zekri, M. and R.C.J. Koo. 1992. Use of controlled release fertilizers for young citrus trees. Scientia Hort. 49:233-241. 